\title{
Evapotranspiration of the Brazilian Pampa Biome: Seasonality and Influential Factors
}

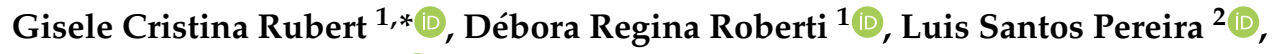 \\ Fernando L. F. Quadros ${ }^{3}{ }^{\circ}$, Haroldo Fraga de Campos Velho ${ }^{4}$ and Osvaldo Luiz Leal de Moraes ${ }^{5}$ \\ 1 Departamento de Física, Universidade Federal de Santa Maria (UFSM), Santa Maria 97105-900 RS, Brazil; \\ debora@ufsm.br \\ 2 Centro de Investigação em Agronomia, Alimentos, Ambiente e Paisagem (LEAF), Instituto \\ Superior de Agronomia, Universidade de Lisboa, Tapada da Ajuda 1349-017 Lisboa, Portugal; \\ luis.santospereira@gmail.com \\ 3 Departamento de Zootecnia, Universidade Federal de Santa Maria (UFSM), \\ Santa Maria 97105-900 RS, Brazil; flfquadros@yahoo.com.br \\ 4 Laboratório de Computação Aplicada, Instituto Nacional de Pesquisas Espaciais, \\ São José dos Campos 12227-010 SP, Brazil; haroldo.camposvelho@inpe.br \\ 5 Centro Nacional de Monitoramento e Alertas de Desastres Naturais, \\ São José dos Campos 12227-010 SP, Brazil; osvaldo.moraes@gmail.com \\ * Correspondence: girubert@gmail.com; Tel.: +55-55-98124-0290
}

Received: 8 November 2018; Accepted: 11 December 2018; Published: 15 December 2018

\begin{abstract}
Experimentally characterizing evapotranspiration (ET) in different biomes around the world is an issue of interest for different areas of science. ET in natural areas of the Brazilian Pampa biome has still not been assessed. In this study, the actual ET (ET $\left.\mathrm{ET}_{\mathrm{act}}\right)$ obtained from eddy covariance measurements over two sites of the Pampa biome was analyzed. The objective was to evaluate the energy partition and seasonal variability of the actual ET of the Pampa biome. Results showed that the latent heat flux was the dominant component in available energy in both the autumn-winter (AW) and spring-summer (SS) periods. Evapotranspiration of the Pampa biome showed strong seasonality, with highest ET rates in the SS period. During the study period, approximately $65 \%$ of the net radiation was used for the evapotranspiration process in the Pampa biome. The annual mean ET rate was $2.45 \mathrm{~mm} \mathrm{~d}^{-1}$. ET did not show to vary significantly between sites, with daily values very similar in both sites. The water availability in the Pampa biome was not a limiting factor for ET, which resulted in a small difference between the reference ET and the actual ET. These results are helpful in achieving a better understanding of the temporal pattern of ET in relation to the landscape of the Pampa biome and its meteorological, soil, and vegetation characteristics.
\end{abstract}

Keywords: actual evapotranspiration; Pampa biome; eddy covariance; evaporative fraction; hysteresis loops

\section{Introduction}

Many experimental studies have been carried out to quantify the evapotranspiration (ET) of different ecosystems and biomes around the world using the eddy covariance (EC) methodology, which is main methodology employed to estimate actual ET from site micrometeorological measurements [1,2]. However, the Pampa biome, characteristic of southern Brazil and part of Argentina and Uruguay, is still not well characterized using that methodology or the quantification of ET and its relationship with environmental variables. In southern Brazil, the Pampa biome presents mostly grassland vegetation interspersed with gallery forests [3]. It is a complex biome, which has different 
vegetation, among which the most representative is fields dominated by grasses. Related studies are lacking and the only recent one refers to characterizing the actual ET of Tifton 85 Bermudagrass as affected by the frequency of cuttings [4].

Although the flora of the Pampa biome totals more than 3000 species, it is dominated by about 450 species of forage grasses and more than 150 species of legumes. The development of this flora is due to the different effects associated with latitude, altitude, and soil fertility. Thus, the Pampa biome presents unique characteristics in terms of vegetation/grass cover [5]. This plant diversity among the species characteristic of the biome's vegetation is what determines the vegetation growth capacity in the seasons of the year, thus defining the balance of the annual production of forage.

Human activities have converted or degraded many areas of this biome [6]. The main use of this region is cattle raising, with a variation of the animal load between the seasons [7]. As a biome that faces fragility of soil, flora, and fauna, sustainable land use in the Brazilian Pampa is only possible if economic activities are adequately conditioned by the soil and environment capacities and adaptations of its plant and animal communities, as well as the related dynamic conditions throughout the biome. It is therefore essential to improve knowledge of vegetation changes due to anthropogenic and/or climatic causes.

In this study, estimates of actual evapotranspiration $\left(\mathrm{ET}_{\mathrm{act}}\right)$ of natural vegetation of the Pampa biome using the eddy covariance methodology [1,2] were analyzed for two sites in southern Brazil-Santa Maria (SMA) and Pedras Altas (PAS)—located about $300 \mathrm{~km}$ from each other. Both sites are within the Pampa and have quite similar vegetation and climate. Their selection owed mainly to differences in soil hydraulic characteristics, with SMA having deep soil with a high water holding capacity and PAS having shallow sandy and stony soil with a small water holding capacity. These differences allowed us to capture the influences of soil characteristics on evapotranspiration fluxes and, thus, on the behavior of actual ET throughout the year.

Only a few eddy covariance studies exist for comparison of evapotranspiration in natural pastures. In Arizona, United States, Krishnan et al. [8] obtained daily values varying from 2.8 to $3.6 \mathrm{~mm} \mathrm{~d}^{-1}$. $\mathrm{Hu}$ et al. [9] showed annual variations of ET of up to $4 \mathrm{~mm} \mathrm{~d}^{-1}$ in a pasture in Inner Mongolia. Trepekli et al. [10], for a coastal grassland in the Mediterranean climate of Greece, reported maximum ET of $8.2 \mathrm{~mm} \mathrm{~d}^{-1}$ in the period of the highest air temperature (summer), while ET values were negligible in winter. Rajan et al. [11] reported that ET was strongly affected by on-site water availability in a managed pasture in the Southern Great Plains, Texas, United States.

In Brazil, evapotranspiration in some different ecosystems has been characterized using eddy covariance data, for example, in the Amazon rainforest [12-14], in the Pantanal biome [15], and in the Cerrado biome [16,17]. However, these ecosystems are in the tropical region, where the seasonality is dominated by precipitation rates. Differently, the Pampa biome is in the subtropical climate, where the seasonality is dominated by solar radiation and presents regular precipitation rates. Therefore, in this study, we intend to answer the following scientific questions about ET in the Pampa biome: (i) How is the partition of energy in the surface? (ii) Which are the physical processes determining the evaporative fraction? (iii) What is the seasonal variation of ET? (iv) What is the relation between actual and reference ET? (v) What is the form of the hysteresis between ET and meteorological variables on a daily timescale?

\section{Materials and Methods}

The study period was from 1 September 2014 to 1 September 2016 for two sites in the Pampa biome in the State of Rio Grande do Sul (RS), Brazil: Santa Maria (SMA) and Pedras Altas (PAS). This period was divided into subperiods that comprised autumn-winter (AW) and spring-summer (SS). The AW period refers to the months of April-September and SS to the months of October-March.

\subsection{Site Description}

The experimental site of SMA-29 $43^{\prime} 27.502^{\prime \prime}$ S; $53^{\circ} 45^{\prime} 36.097^{\prime \prime}$ W; 88-m elevation-is located in the experimental area of the Federal University of Santa Maria, covering 24 ha of natural vegetation 
characteristic of the Pampa biome, near the city of Santa Maria (Figure 1). The experimental area is part of the International Long Term Ecological Research (ILTER) network. The vegetation in the study area, used as pasture for beef cattle, mainly consists of native grasses with a predominance of Andropogon lateralis, Axonopus affinis, Paspalum notatum, and Aristida laevis [18]. This composition is uniformly distributed in the study area [19]. Some studies have already been carried out in this experimental site with objectives focused on the study of the morphogenesis of native species [20,21]. The regional soil type is locally known as a "Planossolo Háplico Eutrofico" according to the exploratory map of soils of RS state [22]. These soils have high fertility and high water retention capacity. The physical properties of the soil in SMA are described in Table 1, representing a deep silt-clay-loam soil. According to the classification of Köppen [23], the climate belongs to the Cfa group, defined as temperate humid with a hot summer.

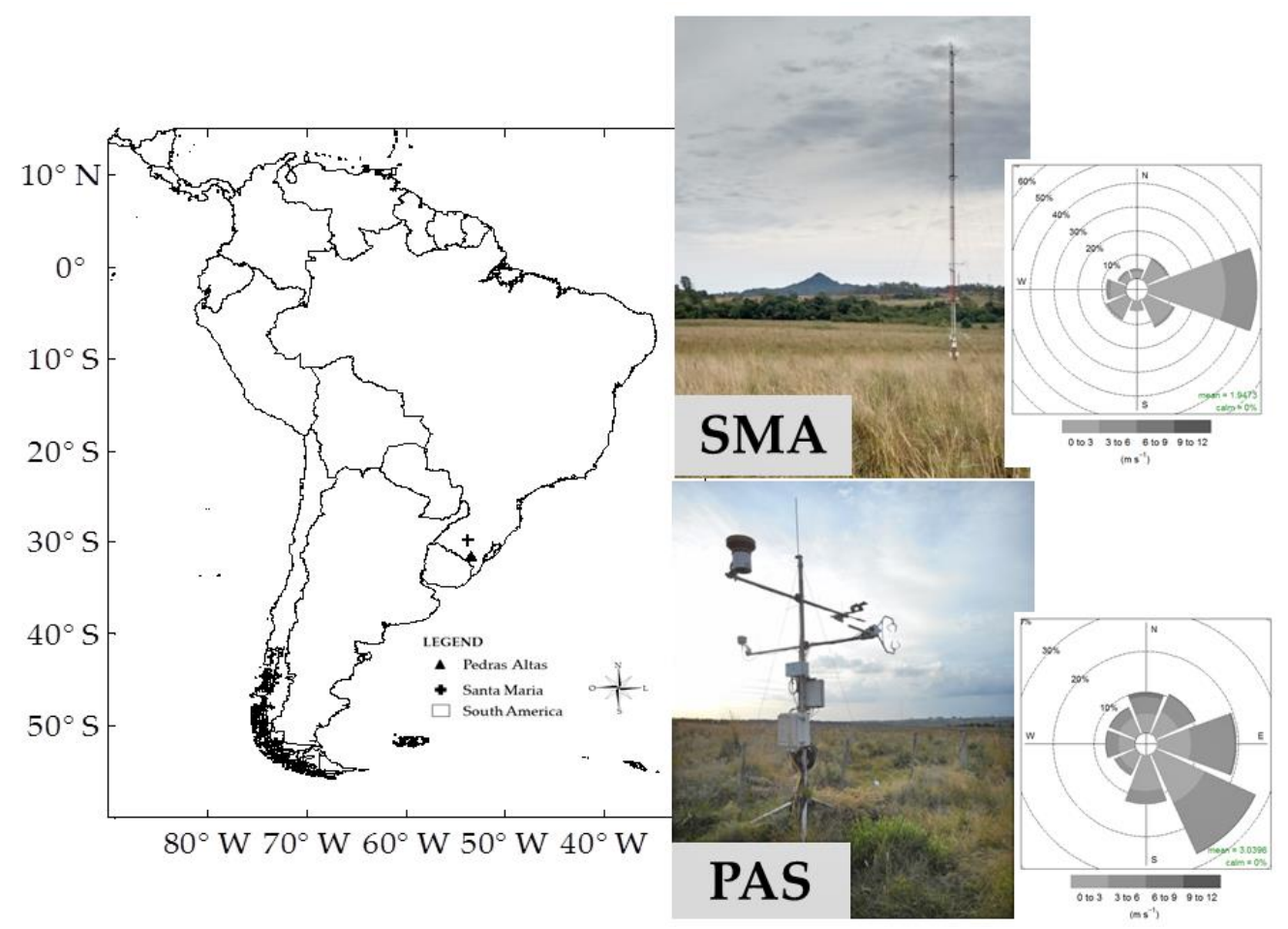

Figure 1. Location of study areas in the Pampa biome-Santa Maria (SMA) and Pedras Altas (PAS) - with the respective wind rose for the study period.

The second site, PAS-31 $43.556^{\prime}$ S; $53^{\circ} 32.036^{\prime} \mathrm{W}$; $395-\mathrm{m}$ elevation-is located on a private farm near the city of Pedras Altas (Figure 1). As with the Santa Maria site, there is no evidence that the area was used for another type of management than livestock. Both sites are situated within similar vegetation physiognomies in the Pampa, with a great diversity of grass species [24]. The phytophysiognomy of the PAS has double extract with predominance of creeping species, mainly stoloniferous and rhizomatous species, and also includes Axonopus affinis, Paspalum notatun, Aeristida laevis, and Iriantus angustifolium. The soil consists of Neosols and Cambisols [22], with rocky outcrops. The soil textural characteristics described in Table 1 correspond to a shallow sandy-loam soil. The climate also belongs to the Cfa classification.

The footprint of the EC was calculated using the software EddyPro ${ }^{\circledR}$ according to the methodology proposed by Kljun et al. [25]. The fetch analysis indicated that about $90 \%$ of the flux originated within a circle with a radius of $115 \mathrm{~m}$ for SMA and $90 \mathrm{~m}$ for PAS. At both sites, there were no obstacles within the footprint area. Wind in the SMA was predominantly eastern (46\%), with its maximum intensity reaching $9 \mathrm{~m} \mathrm{~s}^{-1}$. The wind direction at the PAS was southeast (approximately 27\%), with maximum intensity for the period reaching $11 \mathrm{~m} \mathrm{~s}^{-1}$. 
Table 1. Physical properties of the soil at the experimental sites in the SMA and PAS sites in southern Brazil.

\begin{tabular}{|c|c|c|c|c|c|c|c|}
\hline $\begin{array}{l}\text { Depth * } \\
\text { (cm) }\end{array}$ & $\begin{array}{l}\text { Sand } \\
(\%)\end{array}$ & $\begin{array}{l}\text { Clay } \\
(\%)\end{array}$ & $\begin{array}{l}\text { Silt } \\
(\%)\end{array}$ & $\begin{array}{l}\text { Field Capacity } \theta_{\mathrm{FC}} \\
\qquad\left(\mathrm{m}^{3} \mathrm{~m}^{-3}\right)\end{array}$ & $\begin{array}{l}\text { Permanent Wilting } \\
\text { Point } \theta_{W P} \\
\left(\mathrm{~m}^{3} \mathrm{~m}^{-3}\right)\end{array}$ & $\begin{array}{l}\text { Macroporosity } \\
\left(\mathrm{m}^{3} \mathrm{~m}^{-3}\right)\end{array}$ & $\begin{array}{l}\text { Microporosity } \\
\qquad\left(\mathrm{m}^{3} \mathrm{~m}^{-3}\right)\end{array}$ \\
\hline \multicolumn{8}{|c|}{ Santa Maria } \\
\hline 05 & 47.12 & 16.90 & 35.97 & 0.34 & 0.12 & 0.10 & 0.36 \\
\hline 10 & 42.85 & 20.09 & 37.05 & 0.31 & 0.11 & 0.12 & 0.33 \\
\hline 25 & 40.03 & 22.61 & 37.36 & 0.24 & 0.12 & 0.13 & 0.35 \\
\hline 45 & 34.36 & 32.70 & 32.94 & 0.35 & 0.13 & 0.13 & 0.37 \\
\hline 75 & 26.47 & 43.71 & 29.82 & 0.41 & 0.21 & 0.12 & 0.42 \\
\hline 100 & 28.81 & 40.06 & 31.13 & 0.41 & 0.16 & 0.08 & 0.42 \\
\hline 110 & 17.45 & 34.28 & 48.27 & 0.40 & 0.26 & 0.05 & 0.40 \\
\hline 125 & 17.74 & 27.95 & 54.31 & 0.37 & 0.25 & 0.08 & 0.41 \\
\hline 145 & 14.94 & 30.65 & 54.41 & 0.42 & 0.17 & 0.05 & 0.43 \\
\hline \multicolumn{8}{|c|}{ Pedras Altas } \\
\hline 05 & 59.30 & 0.81 & 39.89 & 0.31 & 0.03 & 0.12 & 0.32 \\
\hline 15 & 58.11 & 0.90 & 40.98 & 0.26 & 0.03 & 0.13 & 0.28 \\
\hline 30 & 56.33 & 1.01 & 42.66 & 0.23 & 0.04 & 0.16 & 0.24 \\
\hline 50 & 54.35 & 1.18 & 44.45 & 0.23 & 0.05 & 0.16 & 0.24 \\
\hline
\end{tabular}

\subsection{Meteorological and Flux Measurements}

The experimental data for both sites were obtained with flux towers. In Santa Maria, the sensor set included a 3D sonic anemometer (Wind Master Pro; Gill Instruments, Hampshire, UK), measuring wind and air temperature components, and a gas analyzer (LI7500, LI-COR Inc., Lincoln, NE, USA), measuring the $\mathrm{H}_{2} \mathrm{O} / \mathrm{CO}_{2}$ concentration at 3-m height sampled at a 10- $\mathrm{Hz}$ frequency from 1 September 2014 to 15 June 2016. After this period, the gas analyzer and the anemometer were replaced by the sensor Integrated $\mathrm{CO}_{2}$ and $\mathrm{H}_{2} \mathrm{O}$ Open-Path Gas Analyzer and a 3D Sonic Anemometer (IRGASON, Campbell Scientific Inc., Logan, UT, USA). At the Pedras Altas site, the same variables were obtained using a sonic anemometer (CSAT3, Campbell Scientific Inc., Logan, UT, USA) and an open path infrared gas analyzer (LI7500, LI-COR Inc., Lincoln, NE, USA), set at the height of $2.5 \mathrm{~m}$ for the entire period.

Atmospheric variables were measured at both sites with the following sensors placed at 3-m height: air temperature and relative humidity (RH) with a thermo-hygrometer (HMP155, Vaisala, Finland), and precipitation with a rainfall sensor (TR525USW, Texas Electronics, Dallas, TX, USA). At the Santa Maria site, net radiation and short-wave incident radiation sensors (CNR4, Kipp \& Zonen, Delft, The Netherlands) were used. At Pedras Altas, measurements of short-wave incident radiation (Li 200S Pyranometer-LI-COR, Lincoln, NE, USA) and net radiation (CNR2-Campbell Scientific Inc., Logan, UT, USA) were performed. At both sites, soil heat flux was measured with soil heat plates (HFP01, Hukseflux Thermal Sensors B.V., Delft, The Netherlands) placed at 0.10-m depth and soil water content was measured using water content reflectometers (CS 616, Campbell Scientific Inc., Logan, UT, USA) at a depth of $0.10 \mathrm{~m}$.

\subsection{Flux Data Processing and Gap Filling}

The eddy covariance method was used in the high-frequency data $(10 \mathrm{~Hz})$ for the determination of the sensible heat flux $(\mathrm{H})$ and latent heat flux (LE) over 30-min block average using EddyPro ${ }^{\circledR}$ software version 6.1 (Li-Cor, Lincoln, NE, USA). The configurations used were double rotation and correction for the effects of density [26], and the high frequency spectral correction was based on the mathematical formulations to model the attenuations due to the instrumental configuration [27]. High and low-pass filter corrections followed the methodology of Moncrieff et al. [28] and Moncrieff et al. [29], respectively. Flux quality tests followed the Mauder and Foken [30] methodology. Angle of attack correction 
for wind components was used according to the Nakai and Shimoyama [31] methodology. Finally, for statistical analysis, spikes removal followed the method of Vickers and Mahrt [32].

In postprocessing, $\mathrm{LE}$ and $\mathrm{H}$ data for periods that showed physically inconsistent and during precipitation events (and up to $60 \mathrm{~min}$ after the event) were discarded. The inconsistency referred to $\mathrm{LE}$ values $<-40 \mathrm{~W} \mathrm{~m}^{-2}$ or $>650 \mathrm{~W} \mathrm{~m}^{-2}$ at SMA and $\mathrm{LE}<-200 \mathrm{~W} \mathrm{~m}^{-2}$ or $>650 \mathrm{~W} \mathrm{~m}^{-2}$ at PAS; $\mathrm{H}$ values $<-60 \mathrm{~W} \mathrm{~m}^{-2}$ or $>300 \mathrm{~W} \mathrm{~m}^{-2}$ at SMA and $\mathrm{H}<-100 \mathrm{~W} \mathrm{~m}^{-2}$ or $>300 \mathrm{~W} \mathrm{~m}^{-2}$ at PAS. After data filtering, which also included malfunctioning periods, the total LE data gap was $30 \%$ at both sites and the total $\mathrm{H}$ data gap was $19 \%$ at SMA and $30 \%$ at PAS.

The energy balance closely followed the Foken et al. [33] methodology. With this methodology, the residual between the available energy $\left(R_{n}-G\right)$ and the energy used for turbulent processes $(H+L E)$ was partitioned between LE and $H$ using the experimental Bowen ratio $(\beta=H / L E)$ for each site.

Gaps in LE and H data were filled using the method proposed by Reichstein et al. [34] with the REddyProc package. In order to complete the missing data of the meteorological variables used in the gap-fill method, data of air temperature, relative humidity, precipitation, and solar radiation collected by the automatic stations of the National Institute of Meteorology (INMET) were used. For the SMA site, the nearest INMET station is approximately $4 \mathrm{~km}$ from the flux tower $\left(29.72^{\circ} \mathrm{W}, 53.72^{\circ} \mathrm{S}\right.$, 103-m elevation). The nearest INMET station to the PAS site is located in the city of Bagé, $67 \mathrm{~km}$ away (at the position: $31.34^{\circ} \mathrm{W}, 54.01^{\circ} \mathrm{S}, 226-\mathrm{m}$ elevation).

\subsection{Evapotranspiration}

The actual evapotranspiration of the Pampa biome $\left(\mathrm{ET}_{\mathrm{act}}\right)$ was estimated from the mean LE in $\mathrm{W} \mathrm{m}^{-2}$, measured with the EC method, thus resulting in

$$
\mathrm{ET}_{\mathrm{act}}=\frac{\mathrm{LE}}{\mathrm{L}_{\mathrm{v}} \rho_{\mathrm{w}}}(1000)(\Delta \mathrm{t})
$$

where $\mathrm{L}_{\mathrm{v}}$ is the latent heat of vaporization $\left(2.45 \times 10^{6} \mathrm{~J} \mathrm{~kg}^{-1}\right), \rho_{\mathrm{w}}$ is the water density $\left(998 \mathrm{~kg} \mathrm{~m}^{-3}\right)$, and $\Delta \mathrm{t}$ is the time scale used in the analysis (the same time scale of LE average). To obtain daily ET $\left(\mathrm{mm} \mathrm{d}^{-1}\right)$, the $\Delta \mathrm{t}$ was $86400 \mathrm{~s}$, and to obtain hourly ET $\left(\mathrm{mm} \mathrm{h}^{-1}\right), \Delta \mathrm{t}$ was $3600 \mathrm{~s}$.

The daily reference evapotranspiration, $\mathrm{ET}_{\mathrm{o}}\left(\mathrm{mm} \mathrm{d}^{-1}\right)$, was computed with the FAO-PM equation [35], defined as

$$
\mathrm{ET}_{0}=\left(\frac{0.408 \Delta\left(\mathrm{R}_{\mathrm{n}}-\mathrm{G}\right)+\gamma \frac{900}{\mathrm{~T}+273} \mathrm{u}_{2}\left(\mathrm{e}_{\mathrm{s}}-\mathrm{e}_{\mathrm{a}}\right)}{\left(\Delta+\gamma\left(1+0.34 \mathrm{u}_{2}\right)\right)}\right)
$$

where $R_{n}$ is the net radiation flux density at the crop surface $\left(M J m^{-2} d^{-1}\right), G$ is the soil heat flux density $\left(\mathrm{MJ} \mathrm{m}^{-2} \mathrm{~d}^{-1}\right), \mathrm{T}$ is the air temperature at 2-m height $\left({ }^{\circ} \mathrm{C}\right), \mathrm{u}_{2}$ is the wind speed at 2-m height $\left(\mathrm{m} \mathrm{s}^{-1}\right), \mathrm{e}_{\mathrm{s}}$ is the saturation vapor pressure $(\mathrm{kPa}), \mathrm{e}_{\mathrm{a}}$ is the actual vapor pressure $(\mathrm{kPa}), \Delta$ is the slope of the vapor pressure curve $\left(\mathrm{kPa}^{\circ} \mathrm{C}^{-1}\right)$, and $\gamma$ is the psychometric constant $\left(\mathrm{kPa}^{\circ} \mathrm{C}^{-1}\right)$. The wind speed at 2-m velocity was estimated using the Allen et al. [35] methodology applied to the measured data.

\section{Results and Discussion}

\subsection{Atmosphere and Soils}

The daily variation of the meteorological variables is shown in Figure 2. The incident short-wave or global radiation, $\mathrm{R}_{\mathrm{g}}$, presented strong seasonality. On average, $\mathrm{R}_{\mathrm{g}}$ in the SS period was $51 \%$ and $56 \%$ higher than in the AW period in the SMA and PAS sites, respectively. For the entire study period, the mean value for $\mathrm{R}_{\mathrm{g}}$ was 173.8 and $182.1 \mathrm{~W} \mathrm{~m}^{-2}$ for SMA and PAS, respectively. Mean values of air temperature were 19.3 and $17.1^{\circ} \mathrm{C}$, which were close to the climatological normal values $\left(18.8^{\circ} \mathrm{C}\right.$ for SMA and $17.9^{\circ} \mathrm{C}$ for PAS) [36]. Comparing AW and SS periods, the air temperature presents 
a well-defined seasonal variation, with daily minimum close to $4{ }^{\circ} \mathrm{C}$ in the $\mathrm{AW}$ season and a daily maximum of $30^{\circ} \mathrm{C}$ in the SS period for both sites.

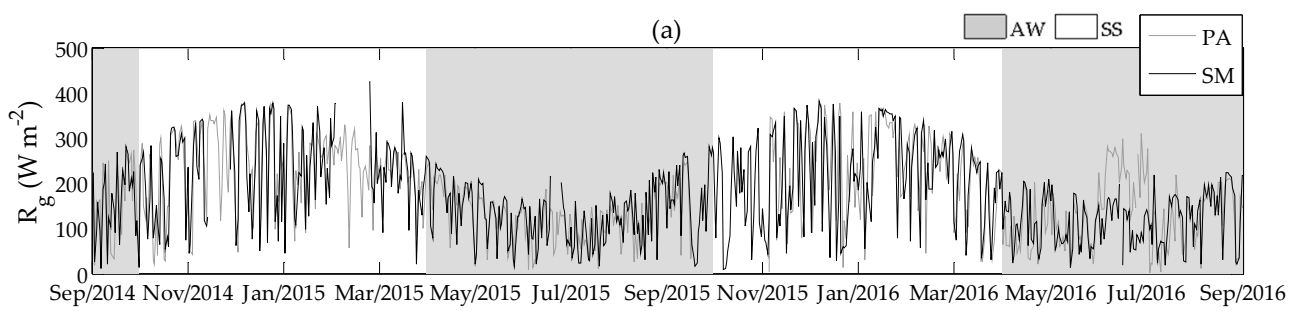

(b)

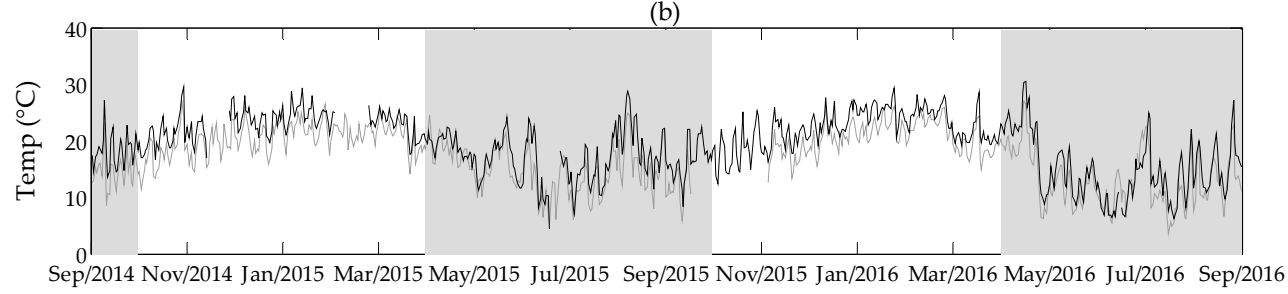

(c)

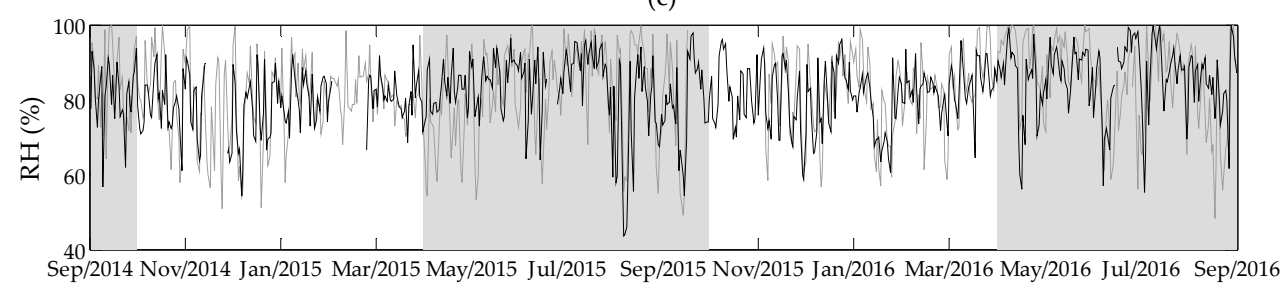

(d)

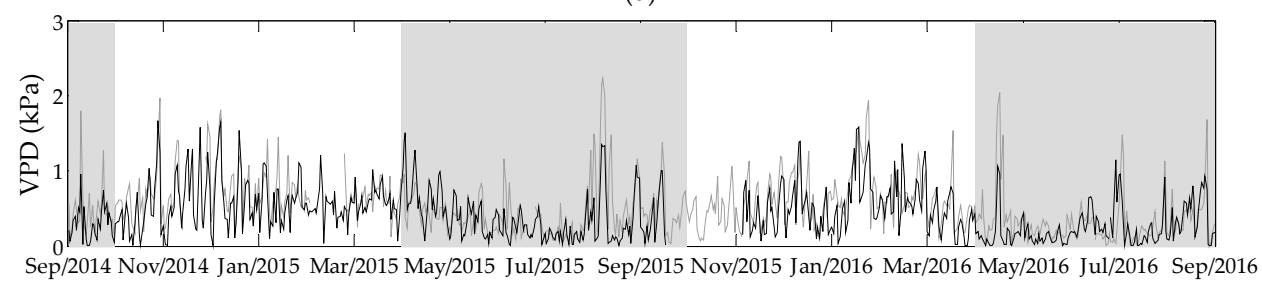

Figure 2. Daily values of meteorological variables: (a) Global Radiation- $\mathrm{R}_{\mathrm{g}}\left(\mathrm{W} \mathrm{m}^{-2}\right)$, (b) Air Temperature-Temp $\left({ }^{\circ} \mathrm{C}\right)$, (c) Relative Humidity-RH (\%), and (d) Vapor Pressure Deficit-VPD $(\mathrm{kPa})$. The hatched areas indicate the autumn-winter $(\mathrm{AW})$ periods.

The RH of the air presented great variability throughout the year, without characterizing a seasonal pattern, and with daily mean values ranging from $43 \%$ to $100 \%$ in SMA and from $48 \%$ to $98 \%$ for PAS. The mean values of RH were $82 \%$ for both sites. The vapor pressure deficit (VPD), defined by the difference between the saturation and actual vapor pressure, ranged from 0 to $2.58 \mathrm{kPa}$ per day. Its dynamics showed a pattern similar to that of air temperature in both sites. On average, for the entire period, the VPD value for the SMA site was greater than for PAS.

Figure 3 shows daily accumulated precipitation, Prec $(\mathrm{mm})$, and soil water content, $\theta\left(\mathrm{m}^{3} \mathrm{~m}^{-3}\right)$. The precipitation was generally well distributed throughout the year and the total values were similar for each site in different years. For the 2014/2015 year (September 2014 to September 2015), the precipitation was $1922 \mathrm{~mm}$ at SMA and $1753 \mathrm{~mm}$ at PAS, and in 2015/2016, it was $2050 \mathrm{~mm}$ at SMA and $1788 \mathrm{~mm}$ at PAS. These values were greater than the climatological average for both sites, $1300 \mathrm{~mm}$ for PAS and $1617 \mathrm{~mm}$ for SMA. The high precipitation values in the study period, especially 2015/2016, were due to the El Niño phenomenon [37], which tends to increase precipitation in southern Brazil. For the AW and SS periods, the accumulated precipitation was 1085.6-1020 mm and 489-1377 mm for SMA and 1105-901 mm and 433.2-1102 mm for PAS, respectively, in 2014/2015-2015/2016. Although the highest cumulative precipitation occurred in the SS period for both sites, the maximum 
daily precipitation occurred in winter for PAS, $122 \mathrm{~mm}$ on 19 July 2015, and in spring for SMA, $126 \mathrm{~mm}$ on 7 October 2015.

The mean for soil water content was approximately $60 \%$ higher in the SMA site than at the PAS site because the soil at SMA is a clay loam soil and thus has a higher water holding capacity than at PAS, where the soil is a shallow sandy loam soil with rocky outcrops, thus having a small water holding capacity. On days when precipitation occurred, the mean values of $\theta$ reached $0.35 \mathrm{~m}^{3} \mathrm{~m}^{-3}$ for both sites. The PAS site showed greater variability of $\theta$ throughout the year.

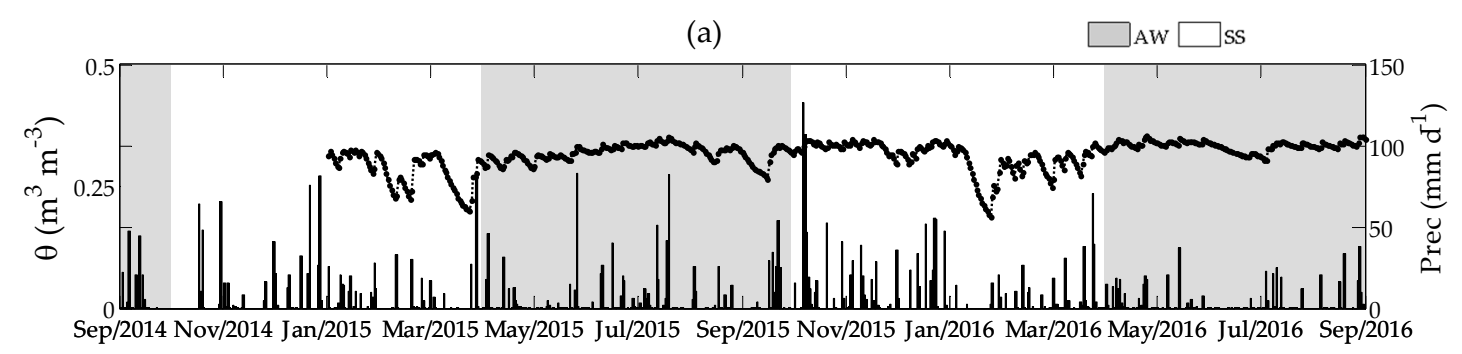

(b)

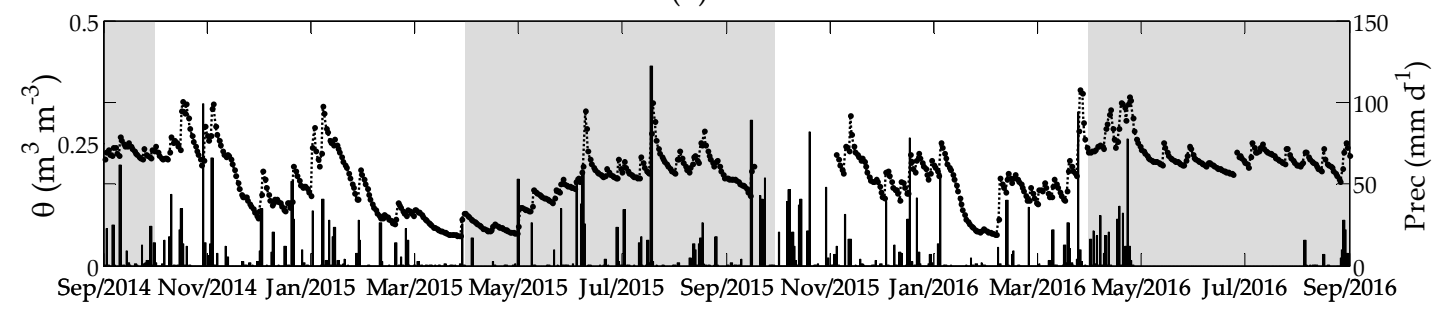

Figure 3. Daily accumulated precipitation, Prec $\left(\mathrm{mm} \mathrm{d}^{-1}\right)$, and volumetric soil moisture at $0.1-\mathrm{m}$ depth, $\theta\left(\mathrm{m}^{3} \mathrm{~m}^{-3}\right)$, for (a) SMA and (b) PAS. The bar plot represents accumulated daily precipitation and the lines represents $\theta$. The hatched areas indicate the AW periods. Observations were not performed from September 2014 to January 2015 at SMA.

\subsection{Energy Balance Closure}

The relationship between the available energy $\left(R_{n}-G\right)$ and the turbulent heat fluxes $(H+L E)$ was used as an indicator of the accuracy of the energy fluxes, $\mathrm{H}$ and LE [38]. This relationship (Figure 4) was obtained with the experimental data but excluded periods when turbulent fluxes were gap filled. The slope of the linear regression was 0.75 for SMA and 0.72 for PAS, representing an underestimation of approximately $25 \%$ of the available energy by the turbulent fluxes.

Most studies in the literature have shown a nonclosure of the energy balance of around $10 \%-30 \%$ [39-43], which is typically related to the underestimation of the turbulent fluxes measured by the eddy covariance method. Aubinet et al. [39] reported that an energy imbalance is expected since, in the accounting of the results, not all the exchanges and processes involved are considered. According to Foken et al. [44], the phenomenon of nonclosure of the energy balance on the surface is not an eddy covariance method problem but a problem related to the heterogeneity of the terrain and its influence on turbulent exchanges. They suggest that sensible and latent heat fluxes can be corrected by using the Bowen's ratio under the assumption that the scalar similarity is fulfilled. This technique was followed in this work and the turbulent fluxes, $\mathrm{H}$ and LE, were corrected after partitioning the residuals of the energy balance using the Bowen's ratio. 


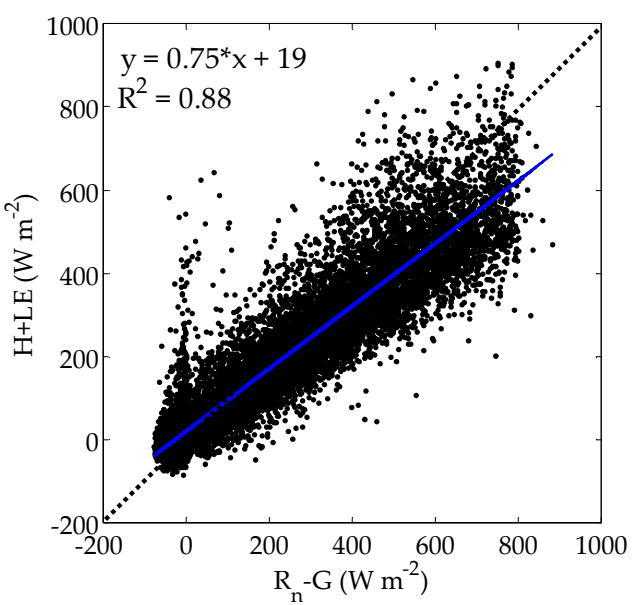

(a)

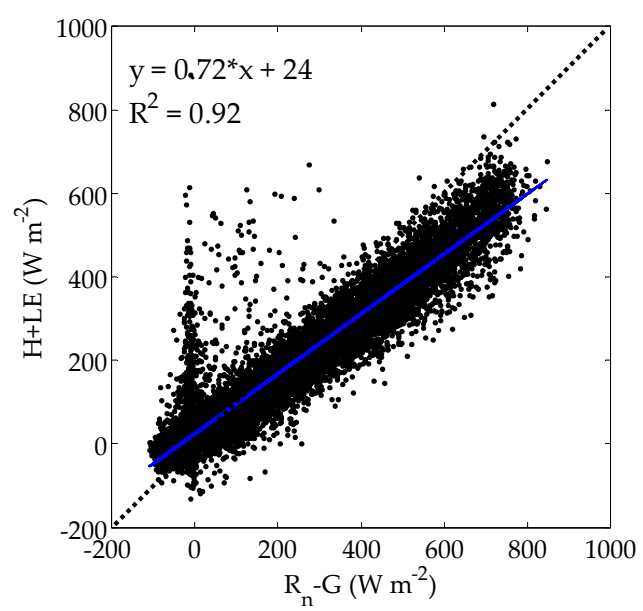

(b)

Figure 4. Scatterplots of the half-hour energy balance closure: the available energy $\left(R_{n}-G\right)$ vs. turbulent heat fluxes $(\mathrm{H}+\mathrm{LE})$ at (a) SMA and (b) PAS. The solid blue line represents the linear fit of the data. For reference, the 1:1 line is also shown (dashed black line).

\subsection{Energy and Water Availability in the Pampa Biome}

The partition of the net radiation, $R_{n}$, between $H$ (heat fraction, $H F=H / R_{n}$ ) and LE (evaporative fraction, $\mathrm{EF}=\mathrm{LE} / \mathrm{R}_{\mathrm{n}}$ ) is shown in Figure 5. Both sites presented a significant difference in the daily values of fractions HF and EF. In general, EF values were greater than HF. EF presented a more significant seasonal variation and EF decreased during the AW period, with minimums between May and August and higher values between September and October, the period of plant growth (increase in biomass production) in the Pampa [45]. Moreover, in the AW season, HF and EF presented greater daily variability, while in the SS period, that variability was small. The magnitude of the difference between HF and EF was higher during SS periods, as influenced by the water and energy availability, with increasing EF values.

(a)

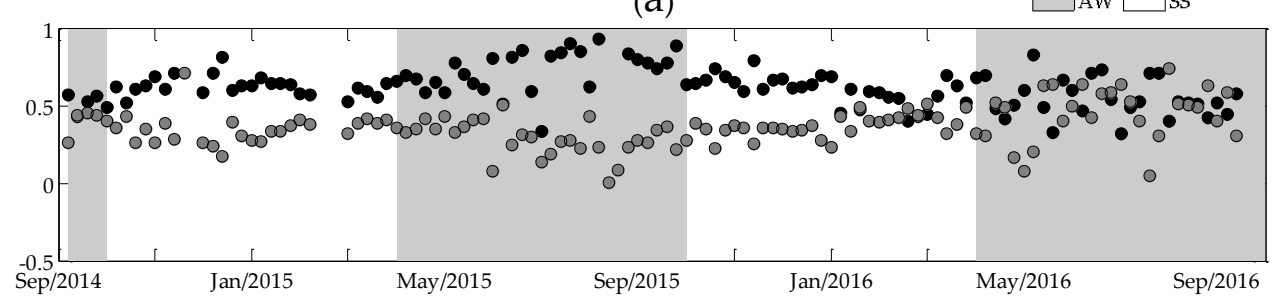

(b)

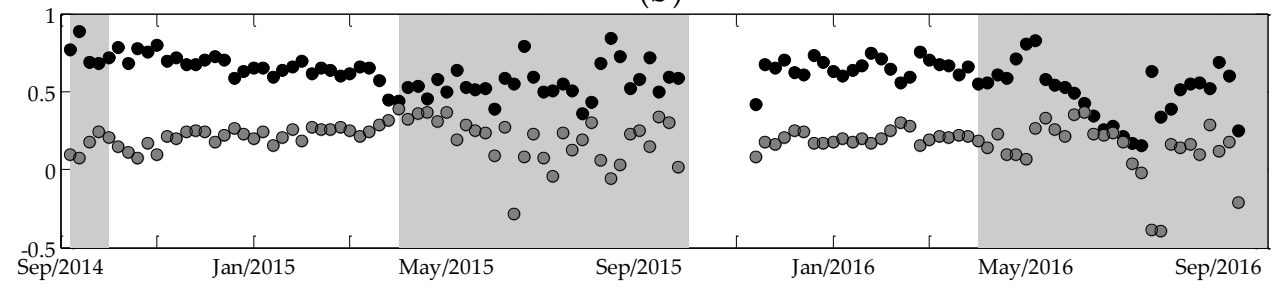

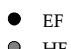

$\mathrm{HF}$

Figure 5. Six-day average of the evaporative fraction $\left(E F=L E / R_{n}\right)$ and heat fraction $\left(H F=H / R_{n}\right)$ for (a) SMA and (b) PAS from September 2014 to September 2016. The hatched areas refer to the AW periods.

The evaporative fraction in the year 2014/2015 was 0.69 for the PAS site and 0.66 for the SMA site. In the year 2015/2016, these values decreased by $8 \%$ and $11 \%$ in the PAS and SMA sites, respectively. The annual mean evaporative fraction for the total study period was 0.64 and 0.66 for the SMA 
and PAS sites, respectively (Table 2). Therefore, approximately $65 \%$ of the $R_{n}$ was used for the evapotranspiration process in the Pampa biome. In pasture vegetation near the Mediterranean coast, Trepekli et al. [10] found that $67 \%$ of the available energy was transformed into LE during the growing season and $20 \%$ during the vegetation senescence period.

Table 2 presents the values of the evaporative fraction in other Brazilian biomes. Da Rocha et al. [13], in the Amazon rainforest, and Sanches et al. [15], in Pantanal, obtained average annual values for the evaporative fraction of about $25 \%$ and $30 \%$, respectively, higher when compared to Pampa. Cabral et al. [17] found for Cerrado an annual mean EF similar to the results obtained in this study. Diferently, Giambelluca et al. [16] obtained EF values of 27\% for Cerrado Denso and 39\% for the Campo Cerrado lower than Pampa.

Table 2. Annual mean of evaporative fraction (EF) of various Brazilian biomes.

\begin{tabular}{ccc}
\hline Biome & EF $=\mathbf{L E} / \mathbf{R}_{\mathbf{n}}$ & Reference \\
\hline Pampa & 0.66 & This study, PAS site \\
Pampa & 0.64 & This study, SMA site \\
Amazon rainforest & 0.86 & Da Rocha et al. [13] \\
Pantanal & 0.80 & Sanches et al. [15] \\
Cerrado & 0.68 & Cabral et al. [17] \\
Cerrado Denso (CD) & 0.48 & Giambelluca et al. [16] \\
Campo Cerrado (CC) & 0.40 & Giambelluca et al. [16] \\
\hline
\end{tabular}

The evaporative fraction can be characterized into two main evapotranspiration regimes as proposed by Seneviratne et al. [46]: soil water limited or energy limited. The reduction of soil water content influences the evaporative fraction because when theta is low, the extraction of water by the roots faces additional resistances and the rate of water extraction results are smaller than the potential (not stressed) ET rate [4,35]. In other words, soil moisture provides a first-order control on land-atmosphere exchanges when it is limiting. Figure 6 shows the relationship between soil water content $(\theta)$ at $0.10-\mathrm{m}$ depth and the evaporative fraction for our sites. The results did not show any peculiar relationship that could help identify those two ET regimes, so a specific analysis was required. From the experimentally measured field capacity $\left(\theta_{\mathrm{FC}}\right)$ and permanent wilting point $\left(\theta_{\mathrm{WP}}\right)$, the average values for these parameters for $0.1 \mathrm{~m}$ were $\theta_{\mathrm{FC}}=0.35$ and $0.26 \mathrm{~m}^{3} \mathrm{~m}^{-3}$, respectively, for SMA and PAS, and $\theta_{\mathrm{WP}}=0.17$ and $0.04 \mathrm{~m}^{3} \mathrm{~m}^{-3}$ for SMA and PAS, respectively. Shuttleworth [47] defined the critical soil water content $\left(\theta_{\mathrm{CRIT}}\right)$ distinguishing those two evapotranspiration regimes (water or energy limited ET) as a typical value of $50 \%-80 \%$ of $\theta_{\mathrm{FC}}$. We assumed $\theta_{\mathrm{CRIT}}$ as $65 \%$ of $\theta_{\mathrm{FC}}$ (a mean value between $50 \%$ and $80 \%$ ), thus resulting in $\theta_{\text {CRIT }}$ values of 0.23 and $0.17 \mathrm{~m}^{3} \mathrm{~m}^{-3}$ for SMA and PAS, respectively.

EF reached a maximum value $\mathrm{EF}_{\max }=0.93$ for $\theta=0.33 \mathrm{~m}^{3} \mathrm{~m}^{-3}$ in $2014 / 2015$ and of $\mathrm{EF}_{\max }=0.88$ for $\theta=0.29 \mathrm{~m}^{3} \mathrm{~m}^{-3}$ in 2015/2016 at the SMA site. For the PAS site, the maximum EFs were $\mathrm{EF}_{\max }=0.88$ for $\theta=0.24 \mathrm{~m}^{3} \mathrm{~m}^{-3}$ in $2014 / 2015$ and of $\mathrm{EF}_{\max }=0.83$ for $\theta=0.31 \mathrm{~m}^{3} \mathrm{~m}^{-3}$ in $2015 / 2016$. These values of $\theta$ for the maximum EF were between $\theta_{\text {CRIT }}$ and $\theta_{\text {FC }}$ at both the SMA and PAS sites for 2014/2015. However, for PAS in 2015/2016, the value of $\theta$ for $E_{\max }$ exceeded the values of field capacity. At the SMA site, for both years of study, ET regimes were energy limited, corresponding to values of soil


of the soil water content and the ET process was controlled by the available energy. At the PAS site, where the soil had a smaller soil water holding capacity and the soil water content remained lower than at SMA, the ET regimes were not well defined. During the two years of analysis, a greater dependence on the soil water content was observed, but values of $\theta$ higher than $\theta_{\text {CRIT }}$ were observed, namely, for $\mathrm{EF}_{\max }$, due to the large and frequent precipitation observed. These results demonstrated that the energy partitioning response to precipitation was more important at the PAS site because its soil had a low water holding capacity. 


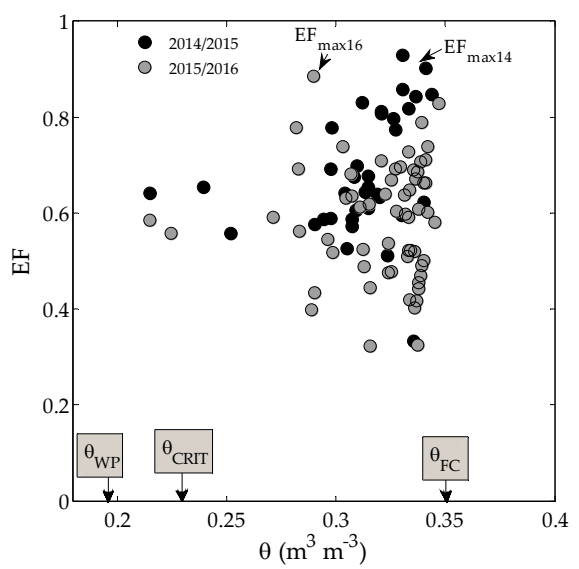

(a)

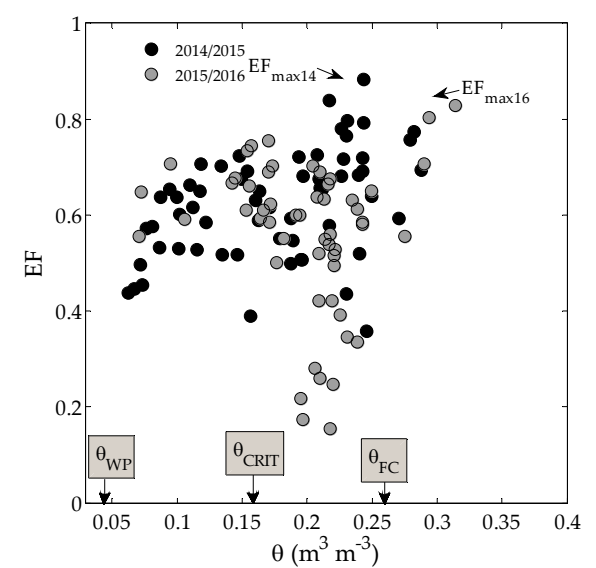

(b)

Figure 6. Evaporative fraction, EF, vs. soil water content, $\theta\left(\mathrm{m}^{3} \mathrm{~m}^{-3}\right)$, for (a) SMA and (b) PAS Gray rectangles indicate the position of values of $\theta_{\mathrm{CRIT}}$ (critical soil water content), $\theta_{\mathrm{FC}}$ (experimentally measured field capacity), and $\theta_{\mathrm{WP}}$ (permanent wilting point).

The analysis of the limiting factors, as well as the partitioning of the available energy in the turbulent fluxes, is of essential importance for the modeling of these surface processes. Bagley et al. [48] pointed out that the variables influencing the surface flux partition may change seasonally, depending on the local vegetation conditions. It could also be noticed from our results that the soil and climate behavior were influenced by seasonality, which also affected the partitioning of the turbulent flux. Gokmen et al. [49] emphasized that the overestimation of ET usually occurs in the hydrological regime where water availability is the limiting factor. Although the relationship between soil water content and evapotranspiration depends on soil type, vegetation type, and vegetation adaptation to dryness [50], the role of soil water content near the surface is significant.

\subsection{Evapotranspiration Variability in the Pampa Biome}

The $\mathrm{ET}_{\text {act }}$ averages for the entire period at the SMA and PAS sites, $2.36 \pm 1.4$ and $2.56 \pm 1.7 \mathrm{~mm} \mathrm{~d}^{-1}$, respectively, were very similar. Assuming the average of both sites, the Brazilian Pampa biome presented a mean annual $\mathrm{ET}_{\text {act }}$ of $2.45 \mathrm{~mm} \mathrm{~d}^{-1}$. The daily $\mathrm{ET}_{\text {act }}$ values ranged from close to 0 to almost $7.1 \mathrm{~mm} \mathrm{~d}^{-1}$ at both sites, with the lowest values in the AW period and the highest values in the SS period (Figure 7), coinciding with the seasonal behavior of global radiation (Figure 2a).

The daily $\mathrm{ET}_{\text {act }}$ decreased dramatically on cloudy days and subsequently increased sharply. On average, the $\mathrm{ET}_{\mathrm{act}}$ in PAS was around $8 \%$ greater than in SMA (Table 3). This may be influenced by the lower wind speed and lower $\mathrm{R}_{\mathrm{g}}$ in SMA, as described in Section 2.1 [51]. The mean $\mathrm{ET}_{\text {act }}$ values during the AW period at the SMA and PAS sites were, respectively, $50 \%$ and $38 \%$ of the mean $\mathrm{ET}_{\text {act }}$ in the SS period.

Between July and September 2015, higher values for $\mathrm{ET}_{\text {act }}$ were observed at the SMA site. By separately analyzing the environmental variables for these days, we observed that high VPD, low relative humidity of the air, high wind intensity reaching $4.7 \mathrm{~m} \mathrm{~s}^{-1}$, and a high air temperature of about $30^{\circ} \mathrm{C}$ did occur (Figure 2). These atypical days of high $\mathrm{ET}_{\text {act }}$ values during $\mathrm{AW}$ were characterized by the "north wind phenomenon", corresponding to the occurrence of hot and humid wind coming from Amazonia and which intensifies near Santa Maria due to its particular topography [52]. For pasture land near the Mediterranean coast, Trepekli et al. [10] reported maximum values for $\mathrm{ET}_{\text {act }}$ of $8.2 \mathrm{~mm} \mathrm{~d}^{-1}$ in summer, the value of which is $15 \%$ greater than those found in our study. Those authors also reported that the values obtained for $\mathrm{ET}_{\text {act }}$ greater than $8 \mathrm{~mm} \mathrm{~d}^{-1}$ were the highest ET rates previously reported in comparable study areas. These values occurred due to advection flows from the sea. However, negligible values for $\mathrm{ET}_{\text {act }}$ were found in winter. 


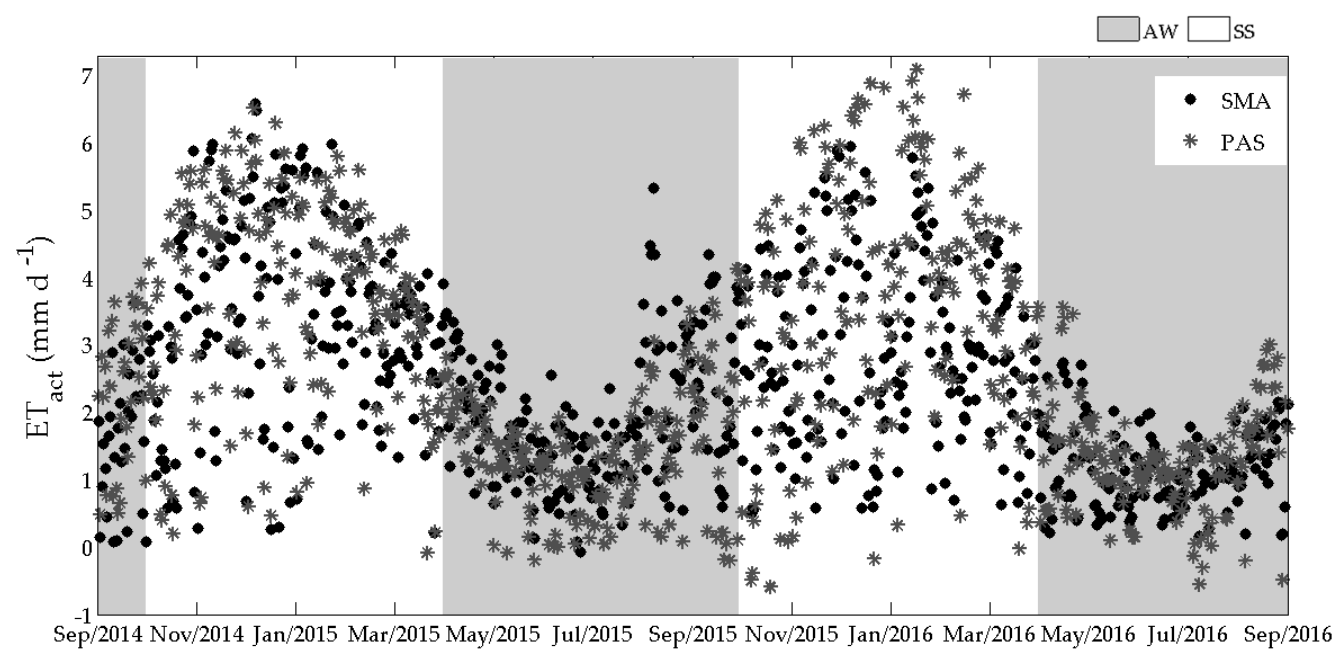

Figure 7. Seasonal variability of actual daily evapotranspiration (ET act) at SMA and PAS sites from September 2014 to September 2016. The hatched areas refer to the AW periods.

Table 3. Daily mean of actual evapotranspiration, $\mathrm{ET}_{\mathrm{act}}\left(\mathrm{mm} \mathrm{d}^{-1}\right)$, and reference evapotranspiration, $\mathrm{ET}_{\mathrm{o}}\left(\mathrm{mm} \mathrm{d}^{-1}\right)$, for the Pampa biome sites of Santa Maria and Pedras Altas relative to various periods.

\begin{tabular}{|c|c|c|c|c|}
\hline \multicolumn{2}{|c|}{ Period } & Site & $\mathrm{ET}_{\text {act }}\left(\mathrm{mm} \mathrm{d}^{-1}\right)$ & $\mathrm{ET}_{\mathrm{o}}\left(\mathrm{mm} \mathrm{d}^{-1}\right)$ \\
\hline \multirow{2}{*}{\multicolumn{2}{|c|}{ Autumn and Winter, AW }} & Santa Maria & 1.58 & 1.93 \\
\hline & & Pedras Altas & 1.42 & 1.73 \\
\hline \multirow{2}{*}{\multicolumn{2}{|c|}{ Spring and Summer, SS }} & Santa Maria & 3.15 & 3.83 \\
\hline & & Pedras Altas & 3.68 & 3.74 \\
\hline \multirow{4}{*}{ Annual } & \multirow{2}{*}{$2014 / 2015$} & Santa Maria & 2.56 & 2.89 \\
\hline & & Pedras Altas & 2.60 & 2.72 \\
\hline & \multirow{2}{*}{$2015 / 2016$} & Santa Maria & 2.16 & 2.79 \\
\hline & & Pedras Altas & 2.49 & 2.82 \\
\hline \multirow{2}{*}{\multicolumn{2}{|c|}{ Two-year period }} & Santa Maria & 2.36 & 2.84 \\
\hline & & Pedras Altas & 2.56 & 2.76 \\
\hline
\end{tabular}

There was a small difference between annual $\mathrm{ET}_{\text {act }}$ average values for the SMA and PAS sites (Table 3), approximately $2 \%$ and $13 \%$ in the years $2014 / 2015$ and $2015 / 2016$, respectively. These differences may be associated with the precipitation and the soil characteristics of each site. Figure 3 shows higher soil moisture for the SMA site because the soil water storage was larger there than at PAS. Annual $\mathrm{ET}_{\mathrm{act}}$ at the PAS site represented $54 \%$ and $51 \%$ of the annual precipitation for 2014/2015 and 2015/2016, respectively. Differently, at the SMA site, $\mathrm{ET}_{\text {act }}$ represented $48 \%$ of the precipitation for $2014 / 2015$, while for $2015 / 2016$, this percentage was reduced to $39 \%$. On average, the actual $\mathrm{ET}_{\text {act }}$ represented $44 \%$ of the observed precipitation for SMA and 53\% for PAS in the two years of study. Therefore, the average annual $\mathrm{ET}_{\mathrm{act}}$ in the Pampa biome $\left(898 \mathrm{~mm}\right.$ year $\left.{ }^{-1}\right)$ represented $48 \%$ of the accumulated precipitation $\left(1878 \mathrm{~mm}\right.$ year $\left.^{-1}\right)$. Krishnan et al. [8] reported a study in a semiarid pasture in North America where precipitation explained more than $80 \%$ of the variance in annual evapotranspiration. Paoloni et al. [53] found on the Argentina Pampa an accumulated annual $\mathrm{ET}_{\text {act }}$ of $1220 \mathrm{~mm}_{\text {year }}{ }^{-1}$, around $35 \%$ greater than in the Brazilian Pampa. For other Brazilians biomes, Goulart et al. [54] reported a cumulative ET of $1337.5 \mathrm{~mm}_{\text {year }}{ }^{-1}$ for the Pantanal, Shuttleworth [55] obtained annual ET of $1393 \mathrm{~mm}$ year $^{-1}$ for the Amazon forest, and Almeida [56] reported $1350 \mathrm{~mm}$ year $^{-1}$ for the Atlantic Forest biome. Da Rocha et al. [13], studying the Amazonia region, reported daily values of $3.96 \mathrm{~mm} \mathrm{~d}^{-1}$ in the dry season and $3.18 \mathrm{~mm} \mathrm{~d}^{-1}$ in the wet season. Therefore, the Brazilian Pampa biome presents a smaller annual ET than most Brazilian biomes (Table 2) but with greater seasonality. Furthermore, Giambelluca et al. [16] reported small seasonal variability for Cerrado Denso 
(CD) and Campo Cerrado (CC) vegetation in the central region of Brazil, with a variation of around $1-1.5 \mathrm{~mm} \mathrm{~d}^{-1}$. The annual mean was 2.25 and $1.91 \mathrm{~mm} \mathrm{~d}^{-1}$ for ET in CD and CC, respectively. Thus, the $\mathrm{ET}_{\mathrm{act}}$ in the Pampa biome was greater and had higher seasonality than both Cerrado biomes in central Brazil.

Daily mean $\mathrm{ET}_{\mathrm{act}}$ and $\mathrm{ET}_{\mathrm{o}}$ exhibited a similar seasonal pattern for both sites in the Pampa biome in southern Brazil. Different from $\mathrm{ET}_{\mathrm{act}}, \mathrm{ET}_{\mathrm{o}}$ was greater (around 3\%) in SMA than at PAS (Table 3). On average, $\mathrm{ET}_{\text {act }}$ represented $83 \%$ of the $\mathrm{ET}_{\mathrm{o}}$ for the $\mathrm{SMA}$ site and about $92 \%$ for PAS (Table 3). These high values of the ratio of $\mathrm{ET}_{\mathrm{act}} / \mathrm{ET}_{\mathrm{o}}$ indicate that the Pampa has high water availability, since natural grass has an ET rate close to the ideal grass crop assumed as a reference crop. Daily maximum $\mathrm{ET}_{\mathrm{o}}$ values were 8 and $7.2 \mathrm{~mm} \mathrm{~d}^{-1}$ for the SMA and PAS sites, respectively. The greatest differences between $\mathrm{ET}_{\mathrm{act}}$ and $\mathrm{ET}_{\mathrm{o}}$ occurred by March 2016 in SMA and by early 2015 in PAS, which were observed in transitional periods between climate seasons, likely due to greater thermal amplitude and higher net radiation that occurred during those periods.

$\mathrm{ET}_{\text {act }}$ was significantly correlated with $\mathrm{ET}_{\mathrm{o}}$ at both sites analyzed (Figure 8). The Pearson correlation coefficient $(\mathrm{r})$ relating $\mathrm{ET}_{\mathrm{act}}$ and $\mathrm{ET}_{\mathrm{o}}$ at the SMA and PAS sites was 0.92 and 0.95 , respectively. These results suggest that $\mathrm{ET}_{\mathrm{o}}$ was a good indicator of $\mathrm{ET}_{\text {act }}$ in the Pampa biome because soil water availability did not restrict $\mathrm{ET}_{\mathrm{act}}$, the values of which were close to $\mathrm{ET}_{\mathrm{o}}$. This indicates that the seasonal variability of $\mathrm{ET}_{\text {act }}$ was determined by atmospheric forcing, mainly, $\mathrm{R}_{\mathrm{n}}$ and VPD. The lowest values of $\mathrm{ET}_{\mathrm{act}}$ and $\mathrm{ET}_{\mathrm{o}}$ were observed during the $\mathrm{AW}$ period, whereas the opposite was observed in the $\mathrm{SS}$ period, then associated with a greater variability of differences between $\mathrm{ET}_{\mathrm{act}}$ and $\mathrm{ET}_{\mathrm{o}}$. The higher correlation between $\mathrm{ET}_{\mathrm{act}}$ and $\mathrm{ET}_{\mathrm{o}}$ was observed at the PAS site, which is coherent with the previous analysis about the energy and water availability in Section 3.4.

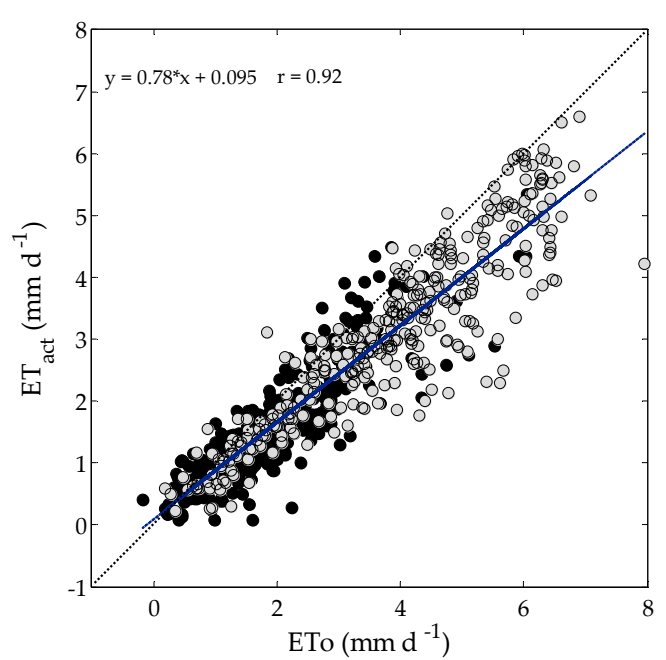

(a)

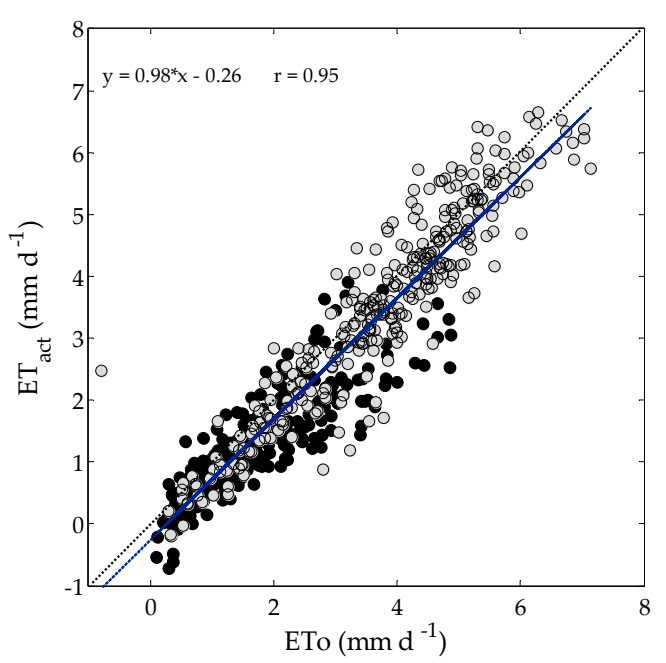

(b)

Figure 8. Scatterplots of daily $\mathrm{ET}_{\mathrm{act}}$ and $\mathrm{ET}_{\mathrm{O}}$ for (a) SMA and (b) PAS. The black dots are for the AW period and the gray dots are for the SS period. The solid blue line represents the linear fit of all data. For reference, the 1:1 line is also shown (dashed black line).

\subsection{Hysteretic Relations between $E T_{\text {act }}$ and Meteorological Variables}

The concept of hysteresis is related to the ability of a system to absorb and recover from disturbances. Hysteresis can therefore be defined as the dependence of a variable response not only on the value of a variable driving but also on its past history [57]. Hysteretic relations were also found between the diurnal variation in evapotranspiration and vapor pressure deficit.

Here, hysteresis loops clockwise in the relationships between $\mathrm{ET}_{\mathrm{act}}$ and vapor pressure deficit (VPD) and air temperature (Temp) were observed in the average daily cycles of 2014/2015 and 2015/2016 (Figure 9), respectively. No hysteretic loops were observed for both sites in $\mathrm{ET}_{\text {act }}$ 
relations with the net radiation; instead, a better $\mathrm{ET}_{\mathrm{act}}$ correlation with this variable was observed. Zheng et al. [58] also reported hysteresis loops on air temperature and VPD relationships with $\mathrm{ET}_{\text {act }}$. Likewise, they did not observe an ET hysteresis response to the net radiation variability.
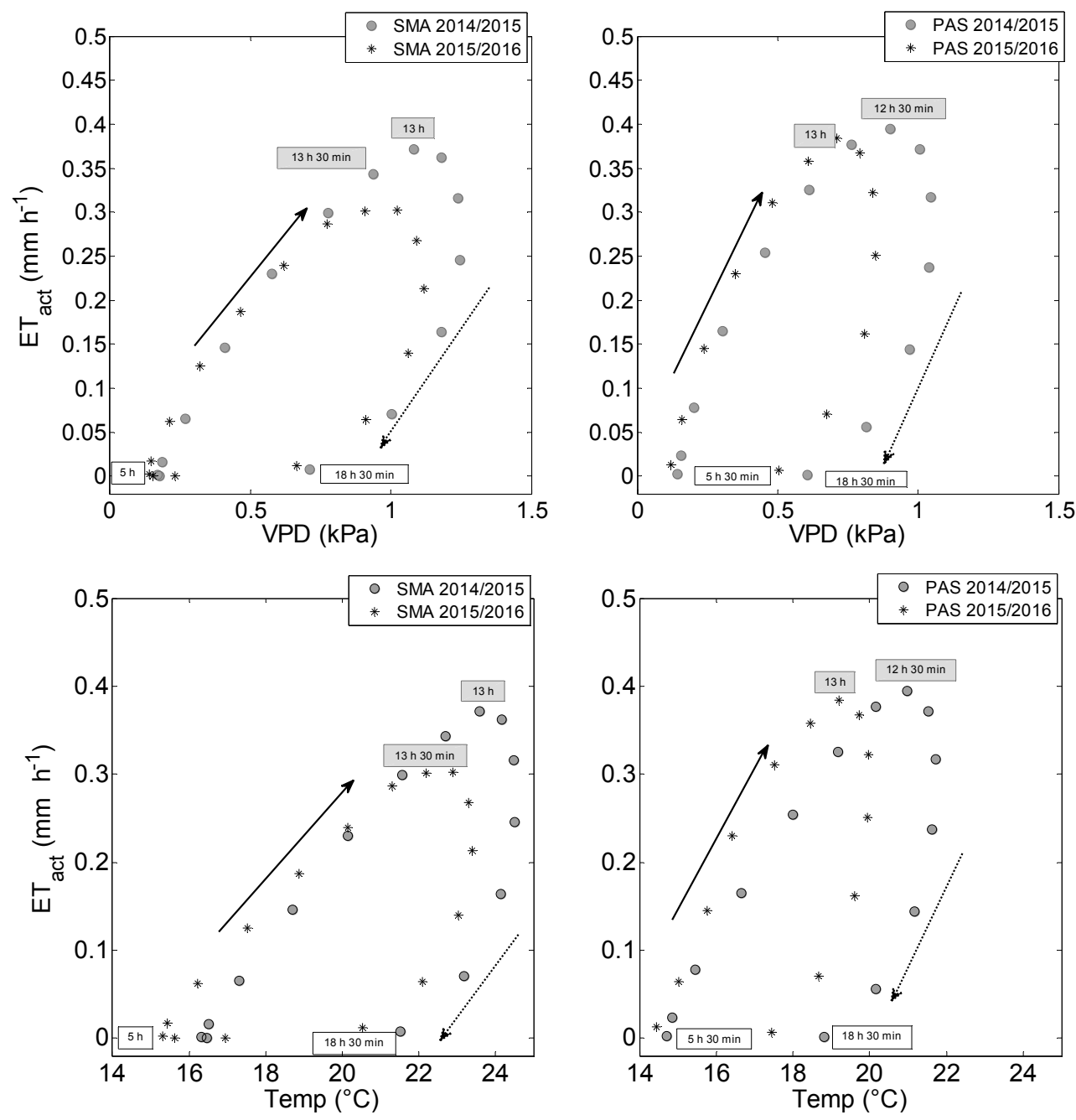

Figure 9. Hysteretic loops relating actual $\mathrm{ET}_{\mathrm{act}}$ and VPD (top panels) and air temperature (bottom panels) for SMA (left panels) and PAS (right panels) for different years. The arrows indicate the direction of the hysteresis effect-morning with a solid arrow and afternoon with a dashed arrow. Gray rectangles indicate the timing (hour) when maximum ET occurs. White rectangles indicate the inversion timing (hour) of the ET signal.

$\mathrm{ET}_{\mathrm{act}}$ values during the night were around zero and were removed from the hysteresis curves. Frequently, the latent heat flux was negative at night in the sites analyzed, indicating dew formation [40]. At night, $\mathrm{ET}_{\text {act }}$ values showed slight variations, but at the beginning of the morning, the $\mathrm{ET}_{\text {act }}$ values increased rapidly and peaked at approximately 12:30 to 1:30 p.m. (local time).

For both sites, $\mathrm{ET}_{\text {act }}$ increased as soon as VPD increased in the morning. $\mathrm{ET}_{\text {act }}$ decreased with the reduction of VPD in the afternoon. A similar behavior was observed by Zheng et al. [58] and Ahrends et al. [59]. The increase in $\mathrm{ET}_{\text {act }}$ in the morning and a subsequent decrease in the afternoon may be directly related to the available energy and the soil water content available to the plants. The opening and/or closing of the stomata may contribute to the appearance of hysteresis. Previous studies have found that stomata responded differently to changes in environmental factors during stomatal control processes, with greater stomatal conductance in the morning [60,61], indicating higher surface conductance and, therefore, a higher evapotranspiration rate compared to the afternoon. Summarizing, 
stomatal control affects canopy transpiration and avoids excessive water loss on days when the vapor pressure deficit is greater.

The hysteresis loops between $\mathrm{ET}_{\mathrm{act}}$ and air temperature for SMA and PAS sites were similar to those found between $\mathrm{ET}_{\mathrm{act}}$ and VPD. The maximum $\mathrm{ET}_{\text {act }}$ for the year 2014/2015 occurred with the air temperature $1{ }^{\circ} \mathrm{C}$ higher than in the year 2015/2016, for both sites. Also, for the $2015 / 2016$, the hysteresis loops shifted to the right side, representing $\mathrm{ET}_{\text {act }}$ that were small in the morning and greater in the afternoon. In 2015/2016, $\mathrm{ET}_{\text {act }}$ in the morning was higher for the same air temperature when compared to the year 2014/2015, which agreed with the fact that the average air temperature was then higher. The climatic conditions of the sites controlled the evaporative rate. Thus, in Pedras Altas, the occurrence of stronger winds favored evapotranspiration.

Regarding the intensity of response of $\mathrm{ET}_{\text {act }}$ to the meteorological variables, we can conclude that the hysteresis was weaker in $\mathrm{ET}_{\mathrm{act}}-\mathrm{Temperature}$ relations when compared to the $\mathrm{ET}_{\text {act }}-\mathrm{VPD}$ relation. The intensity of the hysteresis could be measured through the area formed by the hysteresis loops (normalizing both axes). Thus, the highest areas obtained were in the $\mathrm{ET}_{\mathrm{act}}-\mathrm{VPD}$ ratios for the Pedras Altas site, averaging $7 \%$ of the difference between sites. The values obtained for the areas are presented in Table 4. For $\mathrm{ET}_{\text {act }}$-Temperature relations, the areas had close values for both sites. The largest difference, approximately $8.3 \%$, occurred in hysteresis loops in the $\mathrm{ET}_{\text {act }}-\mathrm{VPD}$ relationship for the Santa Maria site between the years 2014/2015 and 2015/2016. In this way, we can conclude that for the Pampa biome, the $\mathrm{ET}_{\text {act }}$ responded more strongly to the VPD than to temperature, with a hysteresis mean area $74 \%$ larger than that relative to the $\mathrm{ET}_{\mathrm{act}}-$ Temperature relationship.

Table 4. Normalized area of hysteresis between $\mathrm{ET}_{\text {act }}$ and VPD and air temperature for SMA and PAS for different years. The average is represented by mean \pm standard deviation.

\begin{tabular}{|c|c|c|c|}
\hline & Site & $2014 / 2015$ & $2015 / 2016$ \\
\hline \multirow{3}{*}{$\mathrm{ET}_{\mathrm{act}}-\mathrm{VPD}$} & SMA & 0.0764 & 0.0833 \\
\hline & PAS & 0.0876 & 0.0842 \\
\hline & Average & \multicolumn{2}{|c|}{$0.0829 \pm 0.0047$} \\
\hline \multirow{3}{*}{$\mathrm{ET}_{\mathrm{act}}-\mathrm{Temperature}$} & SMA & 0.0220 & 0.0229 \\
\hline & PAS & 0.0228 & 0.0197 \\
\hline & Average & \multicolumn{2}{|c|}{$0.0218 \pm 0.0015$} \\
\hline
\end{tabular}

\section{Conclusions}

The evapotranspiration over the Brazilian Pampa biome was assessed at two sites where observations were performed using eddy covariance. The results allowed us to find answers to various scientific questions:

(i) How is the partition of energy in the surface?

During the study period, approximately $65 \%$ of the available energy was used for evapotranspiration in the Pampa biome. Although there were significant differences in the soil moisture conditions between the sites analyzed, there was no apparent distinction in the energy partition. The latent heat flux was the main energy balance component in both the AW and SS periods. While the latent heat flux presented strong seasonality, the sensible heat flux presented a low amplitude through the year. In general, the energy balance components were higher in the SS period than during AW.

(ii) Which are the physical processes determining the evaporative fraction?

In the analyzed sites of the Pampa biome, both soil moisture and available energy were not identified as limiting factors for evapotranspiration. Although the vegetation of both sites was composed of the same species and the soil properties were different, the high water availability in both sites did not affect the energy partition.

(iii) What is the seasonal variability of $\mathrm{ET}_{\text {act }}$ ? 
The Pampa biome presented strong seasonality of evapotranspiration, with the highest evapotranspiration rates in the SS period, where the vegetation was in active growth and, therefore, had higher biomass production. Even in periods when there was less biomass production of the vegetation in the Pampa, during $\mathrm{AW}$, evapotranspiration corresponded to a high fraction of the available energy. The annual mean of $\mathrm{ET}_{\text {act }}$ was $2.45 \mathrm{~mm} \mathrm{~d}^{-1}$. Daily values of $\mathrm{ET}_{\text {act }}$ were very similar between sites.

(iv) What is the relation of the actual to the reference ET?

The water availability in the Pampa biome was not a limiting factor for $\mathrm{ET}_{\text {act }}$ since LE was the principal fraction of net radiation, which resulted in few differences between the reference ET and the actual ET. These conditions allowed $\mathrm{ET}_{\mathrm{o}}$ to be used as an indicator of ET in the Pampa biome. $\mathrm{ET}_{\text {act }}$ was higher in PAS, while $\mathrm{ET}_{\mathrm{o}}$ was higher in SMA. These differences were not fully clarified in this study, but it could be hypothesized that this behavior related to differences in soil water dynamics influencing $\mathrm{ET}_{\text {act. }}$ It is also assumed that those differences are likely associated with vegetation biophysical control, such as canopy surface conductance and canopy structure, which needs to be further investigated.

(v) What is the relationship between $\mathrm{ET}_{\mathrm{act}}$ and meteorological variables on a daily timescale?

The $\mathrm{ET}_{\text {act }}$ responded linearly to the net radiation but showed hysteresis when related to VPD and air temperature, with similar values for both sites, although responding more strongly to VPD. Clockwise hysteresis loops were observed relative to both variables.

This first study on evapotranspiration of the Pampa biome provides some understanding of the processes and driving forces and factors influencing ET variability. Further studies are required for other areas where ecosystems are differently affected by grazing or by agricultural systems, as well as where vegetation may be influenced by elevation, namely, relative to lowlands. In addition, relating biome ET studies with crop ET studies may also aid in understanding the complexity of these processes.

Summarizing, the Pampa biome is a complex ecosystem where the processes of surface-atmosphere interaction are dependent on weather, climate, soil, and vegetation. In this way, the preservation of this biome is essential for the maintenance of climate, animal, and plant species, as well as local culture.

Author Contributions: The study was planned by G.C.R. and D.R.R., lab data analysis was performed and writing was performed by G.C.R. L.S.P. discussed a few features of the experiments and revised the article writing together with D.R.R. F.L.F.Q. conceived the experiment in Santa Maria Site. D.R.R., H.F.d.C.V., and O.L.L.d.M. obtained the instrumented flux towers.

Funding: The authors acknowledge the National Council for Scientific and Technological Development (CNPq-Brazil), the Coordination for the Improvement of Higher Education Personnel (CAPES-Brazil), the Foundation for Research of Rio Grande do Sul State (FAPERGS), and the Financier of Studies and Projects (FINEP-Brazil) for funding the reported study.

Acknowledgments: The authors acknowledge the staff of the Micrometeorology Lab of the Federal University of Santa Maria for the technical support provided, particularly relative to the flux towers and the eddy covariance instrumentation.

Conflicts of Interest: The authors declare no conflict of interest.

\section{References}

1. Baldocchi, D.D.; Hincks, B.B.; Meyers, T.P. Measuring biosphere atmosphere exchanges of biologycally related gases with micrometeorological methods. Ecology 1988, 69, 1331-1340. [CrossRef]

2. $\quad$ Allen, R.G.; Pereira, L.S.; Howell, T.A.; Jensen, M.E. Evapotranspiration information reporting: I. Factors governing measurement accuracy. Agric. Water Manag. 2011, 98, 899-920. [CrossRef]

3. Overbeck, G.E.; Müller, S.C.; Fidelis, A.; Pfadenhauer, J.; Pillar, V.D.; Blanco, C.C.; Boldrini, I.I.; Both, R.; Forneck, E.D. Brazil's neglected biome: The South Brazilian Campos. Perspect. Plant Ecol. Syst. 2007, 9, 101-116. [CrossRef] 
4. Paredes, P.; Rodrigues, G.J.; Petry, M.T.; Severo, P.O.; Carlesso, R.; Pereira, L.S. Evapotranspiration partition and crop coefficients of Tifton 85 bermudagrass as affected by the frequency of cuttings. Application of the dual Kc approach. Water 2018, 10, 558. [CrossRef]

5. Boldrini, I.I.; Overbeck, G.E.; Trevisan, R. Biodiversidade de plantas. In Os Campos do Sul, 1st ed.; Pillar, V.P., Lange, O., Eds.; UFRGS: Porto Alegre, Brazil, 2015; pp. 53-70. ISBN 978-85-66106-50-3.

6. Pillar, V.D.P.; Müller, S.C.; Castilhos, Z.M.S.; Jacques, A.V.A. Campos Sulinos-Conservação e uso Sustentável da Biodiversidade, 3rd ed.; Ministério do Meio Ambiente: Brasília, Brazil, 2009; 443p, ISBN 978-85-7738-117-3.

7. Nabinger, C.; Ferreira, E.T.; Freitas, A.K.; Carvalho, P.C.F.; Sant'Anna, D.M. Produção animal com base no campo nativo: Aplicações de resultados de pesquisa. In Campos Sulinos-Conservação e uso Sustentável da Biodiversidade, 3rd ed.; Ministério do Meio Ambiente: Brasília, Brazil, 2009; pp. 175-199, ISBN 978-85-7738-117-3.

8. Krishnan, P.; Meyers, T.P.; Scott, R.L.; Kennedy, L.; Heuer, M. Energy exchange and evapotranspiration over two temperate semi-arid grasslands in North America. Agric. For. Meteorol. 2012, 153, 31-44. [CrossRef]

9. Hu, Z.; Wen, X.; Sun, X.; Li, L.; Yu, G.; Lee, X.; Li, S. Partitioning of evapotranspiration through oxygen isotopic measurements of water pools and fluxes in a temperate grassland. J. Geophys. Res. Biogeosci. 2014, 119, 358-371. [CrossRef]

10. Trepekli, A.; Loupa, G.; Rapsomanikis, S. Seasonal evapotranspiration, energy fluxes and turbulence variance characteristics of a Mediterranean coastal grassland. Agric. For. Meteorol. 2016, 226-227, 13-27. [CrossRef]

11. Rajan, N.; Maas, S.J.; Cui, S. Extreme drought effects on summer evapotranspiration and energy balance of a grassland in the Southern Great Plains. Ecohydrology 2015, 8, 1194-1204. [CrossRef]

12. Malhi, Y.; Pegoraro, E.; Nobre, A.D.; Pereira, M.G.P.; Grace, J.; Culf, A.D.; Clement, R. Energy and water dynamics of a central Amazonian rain forest. J. Geophys. Res. 2002, 107, 8061. [CrossRef]

13. Da Rocha, H.R.; Goulden, M.L.; Miller, S.D.; Menton, M.C.; Pinto, L.D.V.O.; de Freitas, H.C.; Silva Figueira, A.M. Seasonality of water and heat fluxes over a tropical forest in eastern Amazonia. Ecol. Appl. 2004, 14, S22-S32. [CrossRef]

14. Da Rocha, H.R.; Manzi, A.; Cabral, O.M.; Miller, S.D.; Goulden, M.L.; Saleska, S.R.; Coupe, N.R.; Wofsy, S.C.; Borma, L.S.; Artaxo, P.; et al. Patterns of water and heat flux across a biome gradient from tropical forest to savanna in Brazil. J. Geophys. Res. 2009, 114, 1-8. [CrossRef]

15. Sanches, L.; Vourlitis, G.L.; Alves, M.C.; Pinto-Júnior, O.B.; Nogueira, J.S. Seasonal patterns of evapotranspiration for a Vochysia divergens Forest in the Brazilian Pantanal. Wetlands 2011, 31, 1215-1225. [CrossRef]

16. Giambelluca, T.W.; Scholz, F.G.; Bucci, S.J.; Meinzer, F.C.; Goldstein, G.; Hoffmann, W.A.; Franco, A.C.; Bucherta, M.P. Evapotranspiration and energy balance of Brazilian savannas with contrasting tree density. Agric. For. Meteorol. 2009, 149, 1365-1376. [CrossRef]

17. Cabral, O.M.R.; da Rocha, H.R.; Gash, J.H.; Freitas, H.C.; Ligo, M.A.V. Water and energy fluxes from a woodland savanna (Cerrado) in southeast Brazil. J. Hydrol. Reg. Stud. 2015, 4, 22-40. [CrossRef]

18. Santos, A.B. dos; de Quadros, F.L.F.; Confortin, A.C.C.; Seibert, L.; Ribeiro, B.S.R.; Severo, P.O.; Casanova, P.T.; Machado, G.G. Rio Grande do Sul State's (Brazil) native grasses morphogenesis under rotational grazing during spring and summer. Ciência Rural 2014, 44, 97-103. [CrossRef]

19. Quadros, F.L.F.; Pillar, V.P. Dinâmica vegetacional em pastagem natural submetida a tratamentos de queima e pastejo. Ciência Rural 2001, 31, 863-868. [CrossRef]

20. Oliveira, L.B.; Soares, E.M.; Jochims, F.; Tiecher, T.; Marques, A.R.; Kuinchtner, B.C.; Rheinheimer, D.S.; de Quadros, F.L.F. Long-Term Effects of Phosphorus on Dynamics of an Overseeded Natural Grassland in Brazil. Rangel. Ecol. Manag. 2015, 68, 445-452. [CrossRef]

21. Confortin, A.C.C.; Quadros, F.L.F.; Santos, A.B.; Seibert, L.; Severo, P.O.; Ribeiro, B.S.R. Leaf tissue fluxes of Pampa biome native grasses submitted to two grazing intervals. Grass Forage Sci. 2016, 71, 1-9. [CrossRef]

22. Instituto Brasileiro de Geografia e Estatística. Available online: http://mapas.ibge.gov.br/tematicos/solos (accessed on 25 May 2017).

23. Kottek, M.; Grieser, J.; Beck, C.; Rudolf, B.; Rubel, F. World Map of the Köppen-Geiger climate classification updated. Meteorol. Z. 2006, 15, 259-263. [CrossRef] 
24. Overbeck, G.E.; Boldrini, I.I.; Carmo, M.R.B.; Garcia, E.N.; Moro, R.S.; Pinto, C.E.; Trevisan, R.; Zannin, A. Fisionomia dos Campos. In Os Campos do Sul, 1st ed.; Pillar, V.P., Lange, O., Eds.; UFRGS: Porto Alegre, Brazil, 2015; pp. 33-41. ISBN 978-85-66106-50-3.

25. Kljun, N.; Calanca, P.; Rotach, M.W.; Schmid, H.P. A simple parameterisation for flux footprint predictions. Bound.-Lay. Meteorol. 2004, 112, 503-523. [CrossRef]

26. Webb, E.K.; Pearman, G.I.; Leuning, R. Correction of flux measurements for density effects due to heat and water vapor transfer. Q. J. R. Meteorol. Soc. 1980, 106, 85-100. [CrossRef]

27. Gash, J.H.C.; Culf, A.D. Applying linear de-trend to eddy correlation data in real time. Bound.-Lay. Meteorol. 1996, 79, 301-306. [CrossRef]

28. Moncrieff, J.; Clement, R.; Finnigan, J.; Meyers, T. Averaging, Detrending, and Filtering of Eddy Covariance Time Series. In Handbook of Micrometeorology; Lee, X., Massman, W., Law, B., Eds.; Springer: Dordrecht, The Netherlands, 2004; Volume 29, pp. 7-31. ISBN 978-1-4020-2265-4.

29. Moncrieff, J.B.; Massheder, J.M.; Bruin, H.; Elbers, J.; Friborg, T.; Heusinkveld, B.; Kabat, P.; Scott, S.; Soegaard, H.; Verhoef, A. A system to measure surface fluxes of momentum, sensible heat, water vapor and carbon dioxide. J. Hydrol. 1997, 188-189, 589-611. [CrossRef]

30. Mauder, M.; Foken, T. Impact of post-field data processing on eddy covariance flux estimates and energy balance closure. Meteorol. Z. 2006, 15, 597-609. [CrossRef]

31. Nakai, T.; Shimoyama, K. Ultrasonic anemometer angle of attack errors under turbulent conditions. Agric. For. Meteorol. 2012, 18, 162-163. [CrossRef]

32. Vickers, D.; Mahrt, L. Quality control and flux sampling problems for tower and aircraft data. J. Atmos. Ocean. Technol. 1997, 14, 512-526. [CrossRef]

33. Foken, T. The energy balance closure problem: An overview. Ecol. Appl. 2008, 18, 1351-1367. [CrossRef]

34. Reichstein, M.; Falge, E.; Baldocchi, D.; Papale, D.; Aubinet, M.; Berbigier, P.; Bernhofer, C.; Buchmann, N.; Gilmanov, T.; Granier, A.; et al. On the separation of net ecosystem exchange into assimilation and ecosystem respiration: Review and improved algorithm. Glob. Chang. Biol. 2005, 11, 1424-1439. [CrossRef]

35. Allen, R.G.; Pereira, L.S.; Raes, D.; Smith, M. Crop Evapotranspiration-Guidelines for Computing Crop Water Requirements; FAO Irrigation and Drainage Paper 56; FAO: Rome, Italy, 1998; p. 300.

36. INMET_Instituto Nacional de Meteorologia. Available online: http://www.inmet.gov.br/portal/ (accessed on 21 March 2018).

37. Climate Prediction Center-NOAA. Available online: http://origin.cpc.ncep.noaa.gov/products/analysis_ monitoring/ensostuff/ONI_v5.php (accessed on 19 October 2017).

38. Wilson, K.B.; Hanson, P.J.; Mulholland, P.J.; Baldocchi, D.D.; Wullschleger, S.D. A comparison of methods for determining forest evapotranspiration and its components: Sap-flow, soil water budget, eddy covariance and catchment water balance. Agric. For. Meteorol. 2001, 106, 153-168. [CrossRef]

39. Aubinet, M.; Grelle, A.; Ibrom, A.; Rannik, U.; Moncrieff, J.; Foken, T.; Kowalski, A.S.; Martin, P.H.; Berbigier, P.; Bernhofer, C.; et al. Estimates of the annual net carbon and water exchange of forests: The EUROFLUX methodology. Adv. Ecol. Res. 2000, 30, 113-175. [CrossRef]

40. Wilson, K.B.; Allen, G.; Falge, E.; Aubinet, M.; Baldocchi, D.; Berbigier, P.; Bernhofer, C.; Ceulemans, R.; Dolman, H.; Field, C.; et al. Energy balance closure at FLUXNET sites. Agric. For. Meteorol. 2002, 113, 223-243. [CrossRef]

41. Kanda, M.; Inagaki, A.; Letzel, M.O.; Raasch, S.; Watanabe, T. LES study of the energy imbalance problem with eddy covariance fluxes. Bound.-Lay. Meteorol. 2004, 110, 381-404. [CrossRef]

42. Sánchez, J.M.; Caselles, V.; Rubio, E.M. Analysis of the energy balance closure over a FLUXNET boreal forest in Finland. Hydrol. Earth Syst. Sci. 2010, 14, 1487-1497. [CrossRef]

43. Barr, A.G.; Van der Kamp, G.; Black, T.A.; McCaughey, J.H.; Nesic, Z. Energy balance closure at the BERMS flux towers in relation to the water balance of the White Gull Creek watershed 1999-2009. Agric. For. Meteorol. 2012, 153, 3-13. [CrossRef]

44. Foken, T.; Leuning, R.; Oncley, S.R.; Mauder, M.; Aubinet, M. Corrections and data quality control. In Eddy Covariance: A Practical Guide to Measurement and Data Analysis; Aubinet, M., Vesala, T., Papale, D., Eds.; Springer: Dordrecht, The Netherlands, 2012; pp. 85-131. ISBN 978-94-007-2350-4.

45. Kuplich, T.M.; Moreira, A.; Fontana, D.C. Série temporal de índice de vegetação sobre diferentes tipologias vegetais no Rio Grande do Sul. Rev. Bras. Eng. Agríc. Ambient. 2013, 17, 1116-1123. [CrossRef] 
46. Seneviratne, S.I.; Corti, T.; Davin, E.L.; Hirschi, M.; Jaeger, E.B.; Lehner, I.; Orlowsky, B.; Teuling, A.J. Investigating soil moisture-climate interactions in a changing climate: A review. Earth Sci. Rev. 2010, 99, 125-161. [CrossRef]

47. Shuttleworth, W.J. Evaporation. In Handbook of Hydrology; Maidment, D.R., Ed.; McGraw-Hill Inc.: New York, NY, USA, 1993; pp. 4.1-4.53.

48. Bagley, J.E.; Kueppers, L.M.; Billesbach, D.P.; Williams, I.N.; Biraud, S.C.; Torn, M.S. The influence of land cover on surface energy partitioning and evaporative fraction regimes in the U.S. Southern Great Plains. J. Geophys. Res. Atmos. 2017, 122, 5793-5807. [CrossRef]

49. Gokmen, M.; Vekerdy, Z.; Verhoef, A.; Verhoef, W.; Batelaan, O.; van der Tol, C. Integration of soil moisture in SEBS for improving evapotranspiration estimation under water stress conditions. Remote Sens. 2012, 121, 261-274. [CrossRef]

50. Teuling, A.J.; Seneviratne, S.I.; Williams, C.; Troch, P.A. Observed timescales of evapotranspiration response to soil moisture. Geophys. Res. Lett. 2006, 33, L23403. [CrossRef]

51. Mortarini, L.; Stefanello, M.; Degrazia, G.; Roberti, D.; Castelli, S.T.; Anfossi, D. Characterization of wind meandering in low-wind-speed conditions. Bound.-Lay. Meteorol. 2016, 161, 165-182. [CrossRef]

52. Arbage, M.C.A.; Degrazia, G.A.; Welter, G.S.; Roberti, D.R.; Acevedo, O.C.; Moraes, O.L.L.; Ferraz, S.T.; Timm, A.U.; Moreira, V.S. Turbulent statistical characteristics associated to the north wind phenomenon in Southern Brazil with application to turbulent diffusion. Phys. A Stat. Mech. Appl. 2008, 387, 4376-4386. [CrossRef]

53. Paoloni, J.D.; Sequeira, M.E.; Fiorentino, C.E.; Amiotti, N.M.; Vazquez, R.J. Waterresources in the semi-arid Pampa-Patagonia transitional region of Argentina. J. Arid Environ. 2003, 53, 257-270. [CrossRef]

54. Goulart, M.A.; Sanches, L.; Vilani, M.T.; Pinto Júnior, O.B. Análise da evapotranspiração por wavelet de Morlet em área de Vochysia divergens Pohl no Pantanal. Rev. Bras. Eng. Agríc. Ambient. 2015, 19, 93-98. [CrossRef]

55. Shuttleworth, W.J. Evaporation from Amazonian rain forest. Proc. R. Soc. 1988, 233, 321-346. [CrossRef]

56. Almeida, A.C.; Soares, J.V. Comparação entre uso de água em plantações de eucalyptus grandis e floresta ombrófila densa (mata atlântica) na costa leste do Brasil. Rev. Árvore 2003, 27, 159-170. [CrossRef]

57. Zuecco, G.; Penna, D.; Borga, M.; van Meerveld, H.J. A versatile index to characterize hysteresis between hydrological variables at the runoff event timescale. Hydrol. Process. 2016, 30, 1449-1466. [CrossRef]

58. Zheng, H.; Wang, Q.; Zhu, X.; Li, Y.; Yu, G. Hysteresis responses of evapotranspiration to meteorological factors at a diel timescale: Patterns and causes. PLoS ONE 2014, 9, e98857. [CrossRef]

59. Ahrends, H.E.; Lind, H.R.; Schween, J.H.; Crewell, S.; Stadler, A.; Rascher, U. Diurnal Dynamics of Wheat Evapotranspiration Derived from Ground-Based Thermal Imagery. Remote Sens. 2014, 6, 9775-9801. [CrossRef]

60. Takagi, K.; Tsuboya, T.; Takahashi, H. Diurnal hysteresis of stomatal and bulk surface conductances in relation to vapor pressure deficit in a cool temperate wetland. Agric. For. Meteorol. 1998, 91, 177-191. [CrossRef]

61. Bai, Y.; Zhu, G.; Su, Y.; Zhang, K.; Han, T.; Ma, J.; Wang, W.; Ma, T.; Feng, L. Hysteresis loops between canopy conductance of grapevines and meteorological variables in an oasis ecosystem. Agric. For. Meteorol. 2015, 214-215, 319-327. [CrossRef]

(C) 2018 by the authors. Licensee MDPI, Basel, Switzerland. This article is an open access article distributed under the terms and conditions of the Creative Commons Attribution (CC BY) license (http:// creativecommons.org/licenses/by/4.0/). 